\title{
Linking Words as an Linguistic Object
}

\section{Pardayev Azamat Baxronovish}

\author{
Docent of the Uzbek linguistics, Candidate of Sciences of Philology, Samarkand State University. \\ Samarkand, Uzbekistan \\ a_pardayev@mail.ru
}

\begin{abstract}
We consider the general characteristics of linking words in the language aspects of the implementation of the correlation function of the nominative and the categorical semantics of the relationaladvanced.
\end{abstract}

Keywords: notional and functional words, part of speech, lexical and grammatical meaning, nominative correlation denominative (nominative) and the function of the categorical semantics of the relational-Advanced.

\section{INTRODUCTION}

The integral part of a systematic course of the studied language (Russian, English, Uzbek, and others) is the section about the function parts of speech (function words), prepositions, conjunctions, particles. Knowledge of the functions and the correct use of linking words are indispensible condition for the development of coherent speech skills, the ability to make up phrases and sentences to find out the relationship of words, their semantics both in the isolated form and in the particular context.

So, prepositions, as well as other linking words, have no independent meaning. They are involved in the establishment of relations between nouns, pronouns, numerals and other words (above all - verbs) in word combinations or sentences. In this the syntax and to some extent the morphological functions of preposition are demonstrated.

The absence of prepositions in the language (for example, in Uzbek as in other Turkish languages) causes serious difficulties in teaching this section of grammar and the need to overcome them on the basic of the comparative method, in particular, in comparison say of Russian prepositions with Uzbek postpositions and affixes.

At present, in a rapidly developing linguistics, the dialectical study of all the phenomena occurring in the language has become the demand of time. A special place in this process takes the characteristic of two ontological nature of linguistic unities in the prospective of these categories of dialectics as general - private, phenomena - case, possibility - case, reason - consequence, form - sence. Even the third included rule of dialectical logic is used at all levels and stages of development of linguistics. It is of particular importance at disclosing the nature of mutually antithetical elements, developing in conjunction with the formation of semantic and structural relations in the system of the language. So, in this respect, it is possible to use the internal rules of the laws of included the third law at disclosing the relevant indications of significant and function words.

The rule of the included the third reflects the oppositions between derivationally correlating linguistic phenomena. If opposites do not cover the whole meaning of the considered concept and between them there are significant additional qualities, then the included the third rule does not apply.

For the most part, the third situation is significant, generating the need for the intermediate conditions of the third law.

The third included rule of dialectical logic incorporates in itself the quality of sides, obviously to each other. In this case two opposite phenomena are united in the third one, having the quality of two opposites.

The third intermediate rule is applied to disclose significant and function words. Thus, the main criterion for selection is the general categorical meaning of these words. 
Conversion of independent words into function words (and even into affixes) is closely connected with historical development of language.

In general, function words (postpositions, conjunctions, particles, etc) are grammatical categories, standing between vocabulary and grammar.

In this case, auxiliary verbs, postpositions - names, postpositions - adverbs, adverbs - particles, allied words and others, by some of their properties are close to significant words on the other properties to the function words.

Auxiliary verbs, nouns and particles firstly, capable to act independently giving auto semantic the lexical meaning, and secondly, they are used as function words and serve to transmit various grammatical meanings, but even so, they do not lose the ability to change the meaning of words (they do not change time, personal endings, the meaning of nouns and so on).

So, when determining the nature of function words and their place in morphology of words, it is necessary to take into account the significant and functional meaning of words.

In order to establish the differences between significant and proper function words, it is important the presence of linking function inherent by proper function words, and this is also morphological invariability, the inability to use them as a single word and their partial similarity with affixes. If we consider that one of the ways of the origin of affixes morphemes goes back to significant function words, then proper function words take an intermediate niche between affixes and significant function words. This can be characterized in the following way: Significant words $\rightarrow$ significant-function word $\rightarrow$ proper-function word $\rightarrow$ function word $\rightarrow$ morpheme (or in Uzbek terminology: mustaqil so 'zlar $\rightarrow$ mustaqil-yordamchi so 'zlar $\rightarrow$ sof yordamchi so 'zlar $\rightarrow$ affiks)

Thus, in each function part of speech, the special category of linking-significant words are marked out acting as a link between the significant and linked parts of speech, thus ensuring the continuity of development of the language system and implementing the system of connection between heterogeneous phenomena. Therefore, when studying significant and function parts of speech, it is permitable to mark out the third group of words - function-significant - acting in opposition to significant and function words included the third, in which the polarity is met, removed the opposition of both groups (Nigmatov X., 1989:22). Function-significant words by their morphological features and abilities to independent usage, relate to a significant part of speech and in a linking function to the category of a function part of speech. Therefore, it seems possible to study them as specific subgroups both in the framework of these significant parts of speech to which they are related functionally (Nigmatov X., 1989: 22).

Among linking-significant words activity used in modern Uzbek language are the words: аввал, илгари, олдин, бурун, қ̧адим, муқ̧аддам, бошда, асосан, асосида, биноан, буйича, мувофиқ, куира, бошқа, бўлак, ташққари, ўзга, ортиқ, буйй, давомида, мобайнида, оша, буйлаб, қараб, мос, бовлик, хуолда...

The transition of words with significant meaning in the category of words with the of auxiliary - a phenomenon, associated with expansion of semantic and stylistic meanings of a words and begins to develop the functional meaning.

In general, in the Uzbek language there are function and significant words partly close to morphological endings. Such words can be used independently. They are capable, to designate auto semantic lexical meaning and serve to indicate different grammatical meanings (post positionalization, conjunctualization, particulation of language).

The language essence of the function words is distinguished by its extremely complexity and multifunctionality.

Thus function words with single-morphemic basic form often come in different lexical classes (lexical and grammatical categories). We compare, for example, different lexical classes presented in the English language by the form but (conjunation, preposition, contact establishing particle, restrictive adverb, relative pronoun, noun in singular and plural forms): last, but, not the least; there was nothing but firelight; but it's what you like; those words were but excuses; there are none but do much the same; that was a large but; his repeated buts are really trying. 
The fundamental difficult when, identifying function words is substantial heterogeneity of words at all. Among them, on one hand, words of significant (or material) content and on the other hand function words. The letters are used only as functional intermediaries in the structure of word combinations and sentences. Nominative correlation is a unifying feature of the entire set of words, ranging from significant substantives and ending by function words - particles. The last ones are approached by their signed role to the affixal morphemes.

The nominative correlation of function words witch significant ones are disclosed in particular, in their direct "negative" in marking out under the text adjacency (Smirnitskiy A., 1952:199). Compare the words in the English language: a / crowd; must /do; by / then and so on.

The nominative correlation is a common expression of significant and linking words function.

For its linguistic interpretation, the terms "the called function" / "the ruminative function" became firmly established. The observed correlation and hence, and the common function is reflected in a written (and dictionary) practice, actualizing function words in a separate writing with significant ones. Thus, in any semantically relevant of dictionary dismemberment, they are clearly delimited from one hand, the meaningful words serving as independent object names and relations to reality, and on the other hand non-meaningful words of relationally - specifying semantics.

In other words, the difference composes of even more differentially in the following: significant words of categorical - semantic features are connected with gender and specific material (directly nominative) signs in their typificated use of words or in lexical semantic variants. As for the function words, the categorical - semantic features, in fact, exhaust their generalizing semantics. These are "operational elements" of vocabulary (Shcherba, L.1957:80), performing only variety of specifying function in any act of utterance formation, their individualizing semantics is so generalized that it is difficult it give interpretation by the way of a dictionary definition.

That is why the function words, considered from the functionally - syntactic point of view, reveal their proximity to the grammatical meanings of words. For example, prepositions and case forms, modal verbs and auxiliary verbs if compare, moreover the syntax characteristics for many function words, in fact exhaust their content part. No wonder, that V.Vinogradov opposing function words to significant called them not the "parts of speech" but "particles of speech". (Vinogradov V., 1975:254).

Indeed, function words, isolated according to functional sign come out in the form of a certain grammatical paradigms. Thus, function words, estimated by their role in the structure of a sentence, they are consistently revealed as exponents of syntactic categories, i.e. implementors of syntactic meanings of phrases and sentences in the appropriate forms - structures, like derivative and relational morphemes in the structure of separate words. For example, namely in this, lies their "pronominal" specific function. Compare:

The mission reached its destination, end all was explained in due course. $\rightarrow$

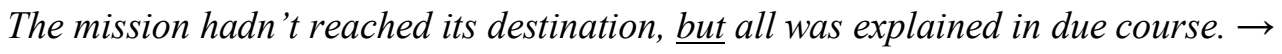

How could all be explained in due course, if the mission never reached its destination?..

The marked role of function words, the totality of which stands out not by the their morphemic structures but by the indicated syntactic functions in the structures clearly revealed in the frameworks of the theory of paradigmatic syntax, developed by modern linguistic ((Strang B. 2011:317-318).

When examining general properties of function words, it is not advisable to ignore those individual characteristics, which are inherent in some of them.

So, in modern Uzbek language, function words are notable for special specificity used as a link.

Based on the characteristics of their lexical - grammatical and functional nature B. Sodikov gives such definition to a function word: "a function word is called as a function (a function element) which is used with nonverbal words or phrases and also with separate verbal forms and serves for realization of the meanings and functions, peculiar to a verb (Sodiкоv B., 1984:15).

Thus, by basing on this position, we can choose here two basic moments:

-firstly, the presence of the linked function is admitted only at these function words which have a verb item, since they can only act as a mean of realization of meanings and functions inherent an a verb; 
- second, the functional sphere of a function word is not limited within bounds of prediction, a function verb can be a means of realization of any meanings and functions inherent in grammatical forms of a verb. In modern Uzbek language in the role of a function word such words as bo 'l, qil, sanaladi, hisoblanadi, deyiladi and also insufficient verb edi are used.

Only the verb bo' $l$ has a universal character which is the sole way to be a means of grammatical meanings and functions realization, inherent in any grammatical forms of the verb. Other verbs are limited in their use. For example, hisoblanadi, sanaladi, deyiladi act in the role of a function word used only as a part of predicate and only in the form of present, future tenses.

\section{Conclusions}

So, examination of some common function words features, allow to make a conclusion that the organizing role for which its grammatical system performs in the language, does not come to the formal regulation of the changing words processes and building itself becomes possible due to, that all the elements of the grammatical system (both significant and function words) have their special semantic content. It is characterized by maximum degree of abstraction from the concrete meanings of the words and their combinations directly reflecting the objects, phenomena and relations of reality.

Grammatically - semantic generalization, realizing in the forms of words and in the forms of the united words in statements, reflect not separate concrete subjects, phenomena and relations of the word, but general signs of classes, subjects and phenomena, general properties of relations between classes. It is this semantical specifics of the grammatical system which stipulates its fundamental role in performing qualitative determination of the language in the whole, that is, in revealing the essence of the language as an object of the reality.

\section{REFERENCES}

Nigmatov H.(1989) Functional morphology of Turkic monuments XI - XII centuries [Text]/ Tashkent: Fan. 192 p.

Shcherba L.(1957) On parts of speech in Russian [Text] //Selected Works of Russian language. - M Moscow. -C. 63-84

Smirnitsky A.(1952) To a question about the word [The problem of "individual expression"] [Text]// Problems of the theory and history of the language. - Moscow. - S. 182-203.

Sodiкоv B. (1984) Bunch in the modern Uzbek language [Text] - Tashkent: Fan. - 88 p.

Strang, B.M. (2011) Modern English structure. - London: Arnold. - 428 p.

Vinogradov V.(1975) Selected Papers: Studies in Russian grammar [Text]. - Moscow: Nauka. - 559 p.

\section{AUTHOR'S BIOGRAPHY}

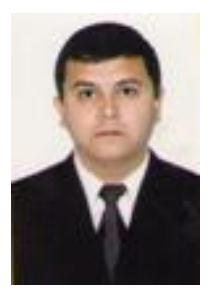

Pardayev Azamat Bakhronovich, - born on 8 march 1975, in the district of Kitob, Kashkadarya region.

The present time docent of the Department of Uzbek linguistics Samarkand State University. He is author monographs of "Uzbek language support Stylistics"(2008), "Auxiliary words in the language system"(2011), "Grammatizatsiya and auxiliary words"(2012), "The place and linguopragmatic analysis of auxiliary parts of speech of the uzbek language in the linguistic system" (2013) and more than 80 scientific articles. At present A. Pardayev is working under the doctoral dissertation on the theme "The place and linguo-pragmatic analysis of auxiliary parts of speech of the uzbek language in the linguistic system". 